\title{
CGRP Promotes the Migration and Invasion of Human Tongue Squamous Cell Carcinoma Cells through Activation of JNK Signaling Pathway
}

Hongxiu Han ${ }^{*}$, Chunxue Yang, Yuanyuan Wang and Yuan Zhang

Department of Pathology, Shanghai Ninth People's Hospital, Shanghai Jiao Tong University School of Medicine, China

"Corresponding author: Hongxiu Han, Department of Pathology, Shanghai Ninth People's Hospital, Shanghai Jiao Tong University School of Medicine, China, Tel: 86-21-56691101(6370); E-mail: hxhan2004@hotmail.com

Received date: May 15, 2018; Accepted date: May 18, 2018; Published date: May 25, 2018

Copyright: $\odot 2018 \mathrm{Han} \mathrm{H}$, et al. This is an open-access article distributed under the terms of the Creative Commons Attribution License, which permits unrestricted use, distribution, and reproduction in any medium, provided the original author and source are credited.

\begin{abstract}
Objective: Increasing evidence indicates that neurogenesis in the cancer is a common phenomenon, which calls us attention to the role of substances released by nerve terminals in the development of cancer. Previous studies demonstrated that neuropeptides influence the migration of prostate cancer cell lines. The mitogen-activated protein kinases (MAPKs) are involved in the migration/invasion of cancer cells. Thus, the current study investigated the effects of calcitonin gene related peptide (CGRP) on the migration and invasion of tongue squamous cell carcinoma (SCC) cells and the potential role of MAPK signaling pathways.
\end{abstract}

Methods: The effects of CGRP on the migration and invasion of human tongue SCC cells (TSCCA cell line) were detected by Transwell assay. The effects of CGRP on the phosphorylated expression of MAPKs including extracellular signal-regulated kinase (ERK), p38 and c-Jun N-terminal kinase (JNK) of TSCCA cells were examined using Western Blot. The effects of inhibitors for ERK, p38 and JNK on the CGRP-induced migration and invasion of TSCCA cells were examined using Transwell assay.

Results: CGRP was shown to promote the migration $(P<0.0001)$ and invasion $(P=0.0008)$ of $T S C C A$ cells by Transwell assay. Western Blot results revealed that the expression of pERK $(P=0.0007)$, pp38 $(P=0.0425)$ and pJNK $(\mathrm{P}=0.0348)$ was increased in TSCCA cells at $1 \mathrm{~h}, 6 \mathrm{~h}$ and $24 \mathrm{~h}$ after CGRP treatment, respectively. JNK inhibitor SP600125, but not ERK inhibitor PD98059 and p38 inhibitor SB203580, attenuated CGRP-induced migration $(P=0.0286)$ and invasion $(P=0.0293)$ of TSCCA cells.

Conclusion: CGRP promotes the migration and invasion of oral SCC cells, which may be through the activation of JNK signaling pathway.

Keywords: Tongue squamous cell carcinoma; CGRP; Migration; Invasion; JNK

\section{Introduction}

Oral cancer is the most common malignancy of the head and neck diagnosed in the world accounting for about $4 \%$ of all cancers, which incidence and mortality have increasing trends yearly worldwide $[1,2]$. Oral squamous cell carcinoma (SCC) is one of the most common types of oral cavity cancers, which includes lips, cheeks, soft palate, gums and salivary glands etc.. It is still a lethal and disabling disease due to tumor invasion, oro-facial destruction and cervical lymph node metastasis [3].

It is well known that invasion and metastasis are essential features of cancer cells. Recently, some studies demonstrated that neurogenesis dose occur in multiple cancers as well as angiogenesis [4-6]. Interestingly, neurogenesis has been indicated to play important role in the development of multiple cancers [7-9]. Neurotransmitters, neuropeptides or synaptic molecules released from nerve endings have a significance influence on tumor migration and invasion even distant metastasis [7-10]. Calcitonin gene-related peptide (CGRP) is a neuropeptide containing 37 amino acid residues discovered in 1982, which is widely distributed in the central nervous system and peripheral organs including the head and is known to be associated with pain sensation, cardiovascular regulation and vasodilation $[11,12]$. Nagakawa et al. demonstrated that CGRP can promote the invasive potentials of prostate cancer cells partially through enhancement of cell motility in vitro [13]. Suzuki et al. reported that serum CGRP levels in prostate cancer patients are positively correlated with tumor grade and staging [14]. Toda et al. demonstrated that CGRP ficilitates the angiogenesis and growth of tumor [15].

Accumulating evidence has shown that the proliferation, migration and invasion of tumor cells are closely related to the mitogen-activated protein kinase signaling pathways $[16,17]$. The involvement of MAPK signaling pathways in the progression of oral cancer has been explored [18]. However, the effects of CGRP on the migration and invasion of oral SCC cells have not been reported. Thus, this study was to investigate the direct effects of CGRP on the migration and invasion of oral SCC cells (TSCCA cell line) by Transwell assay and explore the potential role of MAPK signaling pathways in CGRP-mediated migration and invasion of TSCCA cells.

\section{Materials and Methods}

\section{Cell culture}

TSCCA cell line, human tongue SCC cells, was purchased from Shanghai Zhongqiao Xinzhou Biotechnology Co., Ltd. The cells were 
Citation: Han H, Yang C, Wang Y, Zhang Y (2018) CGRP Promotes the Migration and Invasion of Human Tongue Squamous Cell Carcinoma Cells through Activation of JNK Signaling Pathway. J Carcinog Mutagen 9: 315. doi:10.4172/2157-2518.1000315

Page 2 of 4

cultured in EMEM medium (Gibco, USA) containing 10\% fetal bovine serum (FBS) (Gibco, USA, with the addition of $100 \mathrm{U} / \mathrm{ml}$ penicillin and $0.1 \mathrm{mg} / \mathrm{ml}$ streptomycin (Sigma, USA) in the standard condition $\left(37^{\circ} \mathrm{C}\right.$ and $\left.5 \% \mathrm{CO} 2\right)$.

\section{Cell migration and invasion assays}

The migration of TSCCA cells was determined using Transwell chamber with polycarbonate filter $(8 \mu \mathrm{m}$ sized pores, Millipore, USA). For invasion assay, $60 \mu \mathrm{l}$ diluted Matrigel (1:8, Becton Dickinson and Company, USA) was applied to the top side of the filters. TSCCA cells $\left(3 \times 10^{5}\right.$ cells $/ \mathrm{ml}$ for migration and $1.5 \times 10^{6}$ cells $/ \mathrm{ml}$ for invasion) were seeded onto the upper chamber in $200 \mu \mathrm{l}$ serum-free medium. To examine the effects of CGRP on the cell migration and invasion, 100 nM CGRP (dissolved in 0.1\% DMSO, Sigma, USA) was added into 500 $\mu \mathrm{l}$ medium containing $10 \%$ FBS in the lower chamber. DMSO $(0.1 \%)$ was given as control. To examine the effects of MAPK inhibitors (10 $\mu \mathrm{M}$, dissolved in 1\% DMSO, Tocris Bioscience, UK) for extracellular signal-regulated kinase (ERK), p38 and c-Jun N-terminal kinase (JNK) on CGRP-mediated migration and invasion of TSCCA cells, ERK inhibitor PD98059, p38 inhibitor SB203580 or JNK inhibitor SP600125 was added into the upper chamber and the $100 \mathrm{nM}$ CGRP was added into the lower chamber. CGRP+1\% DMSO was given as control. After incubation for $24 \mathrm{~h}$ at $37^{\circ} \mathrm{C}$, cells were fixed in $4 \%$ formaldehyde for 10 min and stained with crystal violet (Beyotime Institute of Biotechnology Co., Ltd, China) for $20 \mathrm{~min}$ and washed extensively in phosphate buffered saline three times. The migrated or invasive cells on the under-side of the filter were photographed at $100 \times$ magnification and counted in five randomly chosen fields for each sample. The experiment was repeated 3 times. The dose for the drugs used here was based on our preliminary experiments. CGRP dosedependently promotes the migration of TSCCA cells in the preliminary experiments and $100 \mathrm{nM}$ CGRP was chosen in all the formal experiments. All the MAPK inhibitors $(1 \mu \mathrm{M}$ and $10 \mu \mathrm{M})$ were used and the lower dose of all the inhibitors did not affect the CGRPinduced action on TSCCA cells in the preliminary experiments, thus, the higher dose of all the inhibitors was chosen in the formal experiments.

\section{Western blot}

For total cell protein extract, TSCCA cells were homogenized in icecold lysis buffer containing $20 \mathrm{mmol} / \mathrm{L}$ Tris- $\mathrm{HCl}$ ( $\mathrm{pH}$ 8.0), $150 \mathrm{mmol} / \mathrm{L} \mathrm{NaCl}, 1 \mathrm{mmol} / \mathrm{L}$ EDTA, $1 \% \mathrm{NP}-40,1 \mathrm{mmol} / \mathrm{L}$ PMSF, protease inhibitor cocktail (Sigma-Aldrich, USA) and phosphatase inhibitor cocktail (Thermo scientific, USA) for $30 \mathrm{~min}$ at $4^{\circ} \mathrm{C}$ after incubation with $100 \mathrm{nM}$ CGRP for $1 \mathrm{~h}, 6 \mathrm{~h}$ and $24 \mathrm{~h}$. Treatment with $0.1 \%$ DMSO was as control. The lysates were centrifuged at $10,000 \mathrm{~g}$ for $30 \mathrm{~min}$ at $4^{\circ} \mathrm{C}$ and the concentration of protein in each supernatant was determined using a BCA assay (Pierce, USA). Thirty-microgram aliquots were separated on $10 \%$ Tris-glycine gels, the separated proteins were transferred from the gel to the surface of polyvinylidene fluoride (Millipore, USA). The membranes were blocked with 5\% fatfree dry milk in Tris-buffered saline (TBS) containing 0.1\% Tween-20 for $1 \mathrm{~h}$, and were then incubated overnight at $4^{\circ} \mathrm{C}$ with primary rabbit anti-phosphorylated (p) ERK, pp38 or pJNK antibody (1:200, Cell signaling, USA) in 5\% BSA/TBST. Bound primary antibodies were detected with HRP-conjugated anti-rabbit antibody (1:2000, Bio-rad, USA). Immunoreactive bands were visualized using enhanced chemiluminescence (Thermo scientific, USA) and digital imaging was captured with Image Quant LAS 4000 mini (GE Healthcare, USA). The density of specific bands was measured with NIH ImageJ (http:// rsb.info.nih.gov/ij/) software and was normalized against a loading control ( $\beta$-actin).

\section{Statistical analysis}

The Data analysis was carried out using Graphpad Prism 5.0 software. Data were presented as mean \pm SD. The statistical significance of differences between the groups was determined by applying Student's t-test. $\mathrm{P}<0.05$ was considered significantly different.

\section{Results}

\section{CGRP promotes migration and invasion of TSCCA cells}

To evaluate the role of CGRP in migration and invasion of TSCCA cells, we examined the effects induced by CGRP using Transwell assay. As shown in Figure 1, the TSCCA cells with 100 nM CGRP treatment displayed an increased ability to migrate and invade. According to quantitative assessment, the number of migrated cells $(165 \pm 14.2)$ with $100 \mathrm{nM}$ CGRP treatment was significant increased compared to control $(110 \pm 5.3, \mathrm{P}<0.0001)$. Likewise, the number of invasive cells $(68 \pm 23.5)$ with $100 \mathrm{nM}$ CGRP treatment was significant increased compared to control $(13 \pm 2.8, \mathrm{P}=0.0008)$.

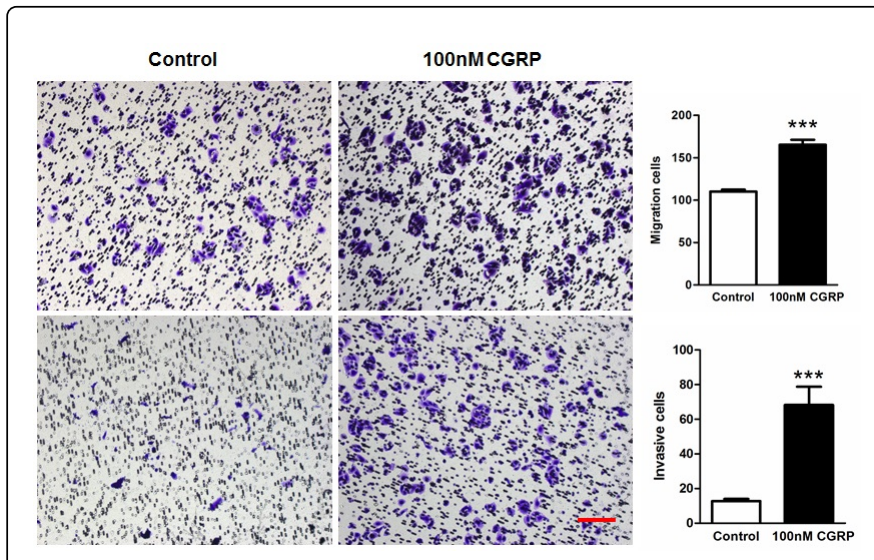

Figure 1: $100 \mathrm{nM}$ CGRP promoted the migration and invasion of TSCCA cells. Left:Photomicrograph representatives of the migration and invasion of TSCCA cells with control and $100 \mathrm{nM}$ CGRP treatment for $24 \mathrm{~h}$ (scale bar: $100 \mu \mathrm{m}$ ); Right: Bar graphs showing that $100 \mathrm{nM}$ CGRP promoted the migration and invasion of TSCCA cells $\left({ }^{* * *} \mathrm{P}<0.001\right.$, vs. control).

\section{Effects of CGRP on phosphorylation of ERK, p38 and JNK}

To explore the effects of CGRP on the activation of MAPKs, we examined the change in protein level of pERK, pp38 and pJNK of TSCCA cells treated with $100 \mathrm{nM}$ CGRP for $1 \mathrm{~h}, 6 \mathrm{~h}$ and $24 \mathrm{~h}$ using Western blot. The expression of pERK of TSCCA cells with $1 \mathrm{~h}$-CGRP treatment was significantly increased compared to control $(\mathrm{P}=0.007)$, but no difference between $6 \mathrm{~h}$ or $24 \mathrm{~h}$ treatment with CGRP and control was shown (Figure 2A). The expression of pp38 of TSCCA cells with $6 \mathrm{~h}$-CGRP treatment, but not $1 \mathrm{~h}$ and $24 \mathrm{~h}$-CGRP treatments, was higher than that of the control $(\mathrm{P}=0.0425$, Figure $2 \mathrm{~B})$. The expression of pJNK of TSCCA cells with $24 \mathrm{~h}$-CGRP treatment, but not $1 \mathrm{~h}$ and 6 
Citation: Han H, Yang C, Wang Y, Zhang Y (2018) CGRP Promotes the Migration and Invasion of Human Tongue Squamous Cell Carcinoma Cells through Activation of JNK Signaling Pathway. J Carcinog Mutagen 9: 315. doi:10.4172/2157-2518.1000315

Page 3 of 4

h-CGRP treatments, was higher than that of the control $(\mathrm{P}=0.0348$, Figure 2C).

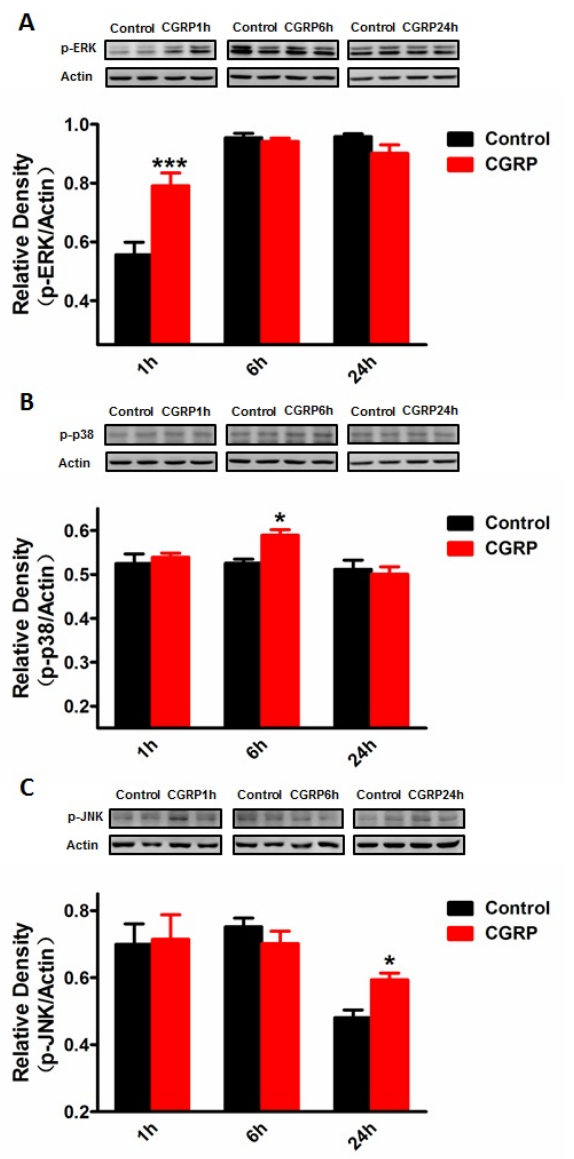

Figure 2: The changes in expression of Perk, pp38 and pJNK of TSCCA cells incubated with $100 \mathrm{nM}$ CGRP for $1 \mathrm{~h}, 6 \mathrm{~h}$ and $24 \mathrm{~h}$, respectively. The expression of pERK (A), pp38 (B) and pJNK (C) was significantly increased compared to control at $1 \mathrm{~h}, 6 \mathrm{~h}$ and $24 \mathrm{~h}$ after CGRP treatment, respectively $\left({ }^{*} \mathrm{P}<0.05,{ }^{* * *} \mathrm{P}<0.001\right.$, vs. Control).

\section{Effects of MAPK inhibitors on the migration and invasion of TCCCA cells induced by CGRP}

To explore the role of MAPK signaling pathways in the CGRPinduced migration and invasion of TSCCA cells, we examined the effects of inhibitors for ERK, p38 and JNK on the CGRP-induced action. As shown in Figure 3, JNK inhibitor SP600125 $(10 \mu \mathrm{M})$ attenuated CGRP-induced migration and invasion of TSCCA cells. According to the quantitative assessment, the number of migrated cells with SP600125 treatment was significantly decreased $(95 \pm 15.5)$ compared to control $(142 \pm 20.8, \mathrm{P}=0.026)$. Similarly, the number of invasive cells with SP600125 treatment was lower $(53 \pm 16.5)$ than that of control $(118 \pm 38.1, \mathrm{P}=0.0293)$. However, both ERK inhibitor PD98059 and p38 inhibitor SB203580 had no effect on CGRP-induced migration and invasion of TSCCA cells.

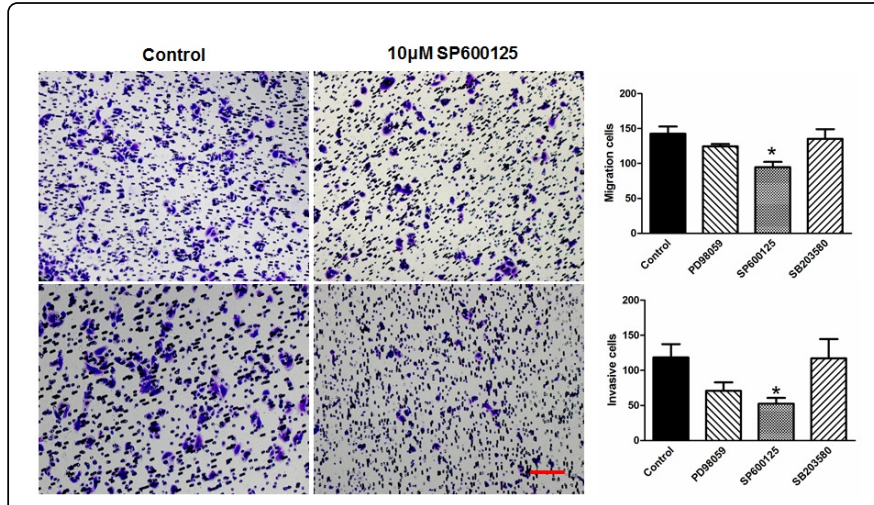

Figure 3: The effects of MAPK inhibitors on CGRP-induced migration and invasion of TSCCA cells. Left: Photomicrograph representatives of the migration and invasion of TSCCA cells with control and SP600125 (scale bar: $100 \mu \mathrm{m}$ ). Right: Bar graphs showing that $100 \mu \mathrm{M}$ SP600125 attenuated CGRP-induced migration and invasion of TSCCA cells $\left({ }^{*} \mathrm{P}<0.05\right.$, vs. Control). However, ERK inhibitor and p38 inhibitor did not affect the CGRPinduced action on TSCCA cells.

\section{Discussion}

Squamous cell carcinoma is the most frequent oral cavity malignancy accounting for over $90 \%$ of oral cancers. Most of the pathological differentiation types are moderate or poor differentiation. Oral cancer patients have a high risk of loco-lymph node metastasis, but the risk of distant metastasis is low, which presents a poor responses to chemotherapy and radiotherapy. Due to the initial symptoms are not paid attention to, patients often present with advanced stage disease [19].

Cancer cells infiltrate into the surrounding tissue and extravagate to distant site, which finally leads to uncontrolled metastasis of cancer cells. It is clear that various molecules and soluble substances in the cancer microenvironment are involved in the development and progress of the cancer. In addition to infiltrating into the peripheral nerves, cancer cells can also release factors such as neurotrophic factors and axonal guidance factors [10] to promote the growth of their own nerves. These neurotrophic factors stimulate the nerve endings or axons to extend into the interior of the tumor [20]. On the other hand, the neurotransmitters, neuropeptides and synaptic molecules affect the tumor growth, angiogenesis and metastasis [7-10,21]. These indicate the important biological effects of neurosignalings in cancer.

CGRP is a neuropeptide that is associated with pain sensation, cardiovascular regulation and vasodilation [11,12]. CGRPimmunoreactive innervation of the head has been demonstrated [12] Our study demonstrated that the neuropeptide CGRP can promote the migration and invasion of TSCCA cells, which provides the direct evidence for the interaction between neuropeptide and metastasis of Oral SCC cells at the cellular level. In agreement with our study, previous report demonstrated that CGRP promotes the migration of prostate cancer cells in vitro [13].

Some studies have been shown that neurotransmitters and other cytokines regulate proliferation, migration and invasion of cancer cells such as human lung adenocarcinoma cells [16], osteosarcoma cells [17] 
Citation: Han H, Yang C, Wang Y, Zhang Y (2018) CGRP Promotes the Migration and Invasion of Human Tongue Squamous Cell Carcinoma Cells through Activation of JNK Signaling Pathway. J Carcinog Mutagen 9: 315. doi:10.4172/2157-2518.1000315

Page 4 of 4

and colon cancer cells [22] through the MAPK signaling pathways. One study also demonstrated that P38alpha and p38delta MAPK isoforms regulate invasion of head and neck SCC cells [23]. In the current study, we found that the increase in the expression of pMAPKs was induced at different time points after CGRP treatment. The expression of pERK, pp38 and pJNK was significantly increased at $1 \mathrm{~h}$, $6 \mathrm{~h}$ and $24 \mathrm{~h}$ after CGRP treatment, respectively. Furthermore, we found that JNK inhibitor SP600125 attenuated CGRP-induced migration and invasion of TSCCA cells, while ERK inhibitor PD98059 and P38 inhibitor SB203580 had no effect on CGRP-induced action. These results suggest that CGRP promotes the migration and invasion of OSCC cells potentially through the JNK signaling pathway. This provides a new clew that CGRP released by nerve terminals in oral SCC micro-environment plays an important role in the invasion and metastasis of cancer cells

\section{Funding Support}

This study was supported by grants from National Natural Science Foundation of China (No. 81272927) and Shanghai Ninth People's Hospital, Shanghai Jiaotong University School of Medicine (syz2015-020).

\section{References}

1. Siegel RL, Miller KD, Jemal A (2018) Cancer statistics, 2018. CA Cancer J Clin 68: 7-30.

2. Miller KD, Siegel RL, Lin CC (2016) Cancer treatment and survivorship statistics, 2016. CA Cancer J Clin 66: 271-289.

3. Thomson PJ (2018) Perspectives on oral squamous cell carcinoma prevention-proliferation, position, progression and prediction. J Oral Pathol Med In Press 12.

4. Ayala GE, Dai H, Powell M, Li R, Ding Y (2008) Cancer-related axonogenesis and neurogenesis in prostate cancer. Clin Cancer Res 14: 7593-7603.

5. Albo D, Akay CL, Marshall CL, Wilks JA, Verstovsek G (2011) Neurogenesis in colorectal cancer is a marker of aggressive tumor behavior and poor outcomes. Cancer 117: 4834-4845.

6. Zhao Q, Yang Y, Liang X, Du G, Liu L, et al. (2014) The clinicopathological significance of neurogenesis in breast cancer. BMC Cancer 14: 484.

7. Magnon C, Hall SJ, Lin J, Xue X, Gerber L, et al. (2013) Autonomic nerve development contributes to prostate cancer progression. Science 341: 1236361.

8. Zhao CM, Hayakawa Y, Kodama Y, Muthupalani S, Westphalen CB, et al. (2014) Denervation supresses gastic tumorigenesis. Sci Transl Med 6: 250ra115.
9. Venkatesh HS, Johung TB, Caretti V, Noll A, Tang Y, et al. (2015) Neuronal activity promotes glioma growth through Neuroligin-3 Secretion. Cell 161: 803-816.

10. Voss MJ, Entschladen F (2010) Tumor interactions with soluble factors and the nervous system. Cell Commun Signal 8: 21 .

11. Amara SG, Jonas V, Rosenfeld MG, Ong ES, Evans RM(1982) Alternative RNA processing in calcitonin gene expression generates mRNAs encoding different polypeptide products. Nature 298: 240-244.

12. Silverman JD, Kruger L (1989) Calcitonin-gene-related-peptideimmunoreactive innervation of the rat head with emphasis on specialized sensory structures. J Comp Neurol 280: 303-330.

13. Nagakawa O, Ogasawara M, Murata J, Fuse H, Saiki I (2001) Effect of prostatic neuropeptides on migration of prostate cancer cell lines. Int J Urol 8: 65-70.

14. Suzuki K, Kobayashi Y, Morita T (2006) Serum calcitonin gene-related peptide levels in untreated prostate cancer patients. Int J Urol 13: 781-784

15. Toda M, Suzuki T, Hosono K, Hayashi I, Hashiba S, et al. (2008) Neuronal system-dependent facilitation of tumor angiogenesis and tumor growth by calcitonin gene-related peptide. Proc Natl Acad Sci 105: 13550-13555.

16. Ni L, Feng Y, Wan H, Ma Q, Fan L, et al. (2012) Angiotensin-(1-7) inhibits the migration and invasion of A549 human lung adenocarcinoma cells through inactivation of the PI3K/Akt and MAPK signaling pathways. Oncol Rep 27: 783-790.

17. Zhang Y, Tang YJ, Li ZH, Pan F, Huang K, et al. (2013) Kiss1 inhibits growth and invasion of osteosarcoma cells through inhibition of the MAPK pathway. Eur J Histochem 57: e30.

18. Peng Q, Deng Z, Pan H, Gu L, Liu O, et al. (2018) Mitogen-activated protein kinase signaling pathway in oral cancer. Oncol Lett 15: 1379-1388.

19. Montero PH, Patel SG (2015) Cancer of the oral cavity. Surg Oncol Clin N Am 24: 491-508.

20. Mancino M, Ametller E, Gascon P, Almendro V (2011) The neuronal influence on tumor progression. Biochim Biophys Acta 1816: 105-118.

21. Thaker PH, Han LY, Kamat AA, Arevalo JM, Talahashi R, et al. (2006) Chronic stress promotes tumor growth and angiogenesis in a mouse model of ovarian carcinoma. Nat Med 12: 939-944.

22. Ahmed N, Oliva K, Wang Y, Quinn M, Rice G (2003) Downregulation of urokinase plasminogen activator receptor expression inhibits erk signalling with concomitant suppression of invasiveness due to loss of upar-betal integrin complex in colon cancer cells. Br J Cancer 89: 374-384.

23. Junttila MR, Ala Aho R, Jokilehto T, Peltonen J, Kallajoli M, et al. (2007) P38alpha and p38delta mitogen-activated protein kinase isoforms regulate invasion and growth of head and neck squamous carcinoma cells. Oncogene 26: 5267-5279. 